\title{
Kajian Hidrolika Bangunan Pelimpah Samping (Side Channel Spillway) Bendungan Pomalaa Kabupaten Kolaka Provinsi Sulawesi Tenggara Dengan Uji Model Fisik $1: 40$
}

\author{
R Susenatama Jatayu Paksi', Very Dermawan', Ussy \\ Andawayanti $^{1}$ \\ ${ }^{1}$ Jurusan Teknik Pengairan, Fakultas Teknik, Universitas Brawijaya, \\ Jalan MT. Haryono No. 167, Malang, 65145, Indonesia \\ *korespondensi Email: islamsena36@gmail.com
}

\begin{abstract}
Pomalaa Dam designed to settle nickel mining wasted material ran by PT. Vale Indonesia, a physical model test is required to accomplish the design. This study aimed to determine the comparison of Pomalaa Dam side-channel spillway hydraulic condition between physical model test and theoretical analysis. In the analysis of the water level profile, debits of Q100th, Q1000th, and QPMF were examined. Spillway hydraulic analyzed by continuity equation with $\mathrm{Cd}$ calculation using the Iwasaki method. The water level in the transition channel and chute way calculated by the energy equation with the standard stage method. The side ditch and stilling basin hydraulic analyzed by momentum equations law. The vibration flow risk and cavitation respectively analyzed using Vendernikov-Montuori numbers and dimensionless parameters. The results of the hydraulic model test show that in the original design there is a non-uniform flow in the transition channel, the piezometer shows negative pressure in the chute channels section 2 and 3, but still safe. But the cavitation calculation using water velocity (v) and water depth (h) shows that cavitation occurred in the chute channels section 2 and 3 at the Q100th and Q1000th discharge and supercritical flow occurred at the end channel after the energy dissipator.
\end{abstract}

Keywords: Energy dissipator, Hydraulics analysis, Side channel spillway, Water level profile

Abstrak: Bendungan Pomalaa direncakan berfungsi untuk mengendapkan material buangan dari proses pertambangan nikel PT Vale Indonesia, untuk menyempurnakan desainnya dibutuhkan uji model fisik. Penelitian ini bertujuan untuk mengetahui kesesuaian hasil uji model fisik Bendungan 
Pomalaa terhadap kondisi hidrolika aliran original design dengan perhitungan analitis. Perhitungan analitis profil muka air dikaji dengan debit Q100th, Q1000th, dan QPMF. Analisa hidrolika pelimpah menggunakan persamaan kontinuitas dengan perhitungan koefisien debit Cd menggunakan pendekatan metode Iwasaki. Perhitungan tinggi muka air pada saluran transisi dan peluncur menggunakan persamaan energi dengan metode tahapan standar. Analisa hidrolika pada pada saluran samping dan peredam energi menggunakan hukum persamaan momentum. Bahaya kavitasi dianalisis menggunakan bilangan Vendernikov - Montuori dan parameter tak berdimensi. Hasil pengujian model menunjukkan original desain terjadi aliran tidak seragam pada saluran transisi, piezometer menunjukkan adanya tekanan negatif pada saluran peluncur 2 dan 3, tetapi masih batas aman. Tetapi perhitungan kavitasi menggunakan kecepatan air (v) dan kedalaman air (h) menunjukkan adanya kavitasi di saluran peluncur 2 dan 3 pada debit Q100th dan Q1000th, serta terjadi aliran superkritis pada saluran akhir setelah peredam energi.

Kata Kunci: Analisis hidrolika, Pelimpah samping, Peredam energi, Profil muka air

\section{Pendahuluan}

Kegiatan pertambangan nikel ini selain memberikan dampak positif dalam meningkatkan Pendapatan Asli Daerah (PAD) serta terciptanya lapangan pekerjaan bagi masyarakat lokal maupun masyarakat di luar lokasi pertambangan juga akan memberikan dampak negatif yaitu dapat merusak lingkungan apabila tidak ada penanganan dalam pengelolaan limbah pertambangan, sehingga guna mendukung pertambangan yang berkelanjutan, maka suatu perusahaan harus melakukan treatment untuk memperbaiki kondisi lingkungan yang rusak atau yang akan tercemar. Salah satu treatment yang bisa dilakukan adalah dengan membangun bendugan-bendungan atau tailing dam yang telah diilakukan oleh salah satu perusahaan yang mengelola pertambangan nikel tersebut adalah PT Vale Indonesia Tbk yang terletak di Kabupaten Kolaka Provinsi Sulawesi Tenggara.

Bendungan Pomalaa yang berada di PT Vale Indonesia Tbk terletak pada area konsensi Blok Pomala yang diharapkan dapat berfungsi sebagai bendungan yang dapat mengendapkan material atau partikel buangan dari proses pertambangan nikel yang ada pada PT Vale Indonesia, maka untuk menyempurnakan dan memantapkan penyusunan detil desain demi terwujudnya tujuan diatas dibutuhkan suatu uji model fisik terhadap perencanaan Bendungan Pomalaa di Kabupaten Kolaka Provinsi Sulawesi Tenggara. Dengan harapan dapat melihat pola perilaku hidraulika yang terjadi sesuai dengan apa yang telah direncanakan sebelumnya [1].

Penelitian ini bertujuan untuk mengetahui kesesuaian hasil pengukuran uji model fisik Bendungan Pomalaa terhadap kondisi hidrolika aliran original design, dengan hasil perhitungan analitis dan untuk mengetahui rekomendasi perubahan untuk mendapatkan hasil hidrolika aliran yang baik pada sistem pelimpah. 


\section{Bahan dan Metode}

\subsection{Fasilitas Pengujian}

Pelaksanaan Uji Model Fisik Side Channel Spillway Bendungan Pomalaa, menggunakan fasilitas yang ada di Laboratorium Hidrolika Terapan Fakultas Teknik Universitas Brawijaya Malang. Percobaan model menggunakan alat pendukung berikut :

1. Pompa listrik sebanyak 4 buah dengan kapasitas masing-masing sebesar $25 \mathrm{l} / \mathrm{dt}, 30$ 1/dt, 30 lt/dt dan 45 l/dt.

2. Kolam penampung air yang berfungsi sebagai sistem distribusi air. Bangunan ukur debit Rechbox dengan ukuran yang disesuaikan dengan standar terbuat dari fiberglass tebal $5 \mathrm{~mm}$.

3. Meteran taraf (point gauge) sebagai alat pengukur tinggi muka air, sipat datar, bak ukur, pengukuran kecepatan berupa tabung pitot, small current meter, dan alat pengukur tekanan berupa piezome Alat pengukur tinggi muka air berupa meteran taraf (point gauge), pengukuran kecepatan berupa tabung pitot dan small current meter.

4. Model bangunan yang terdiri dari saluran pelimpah, saluran transisi, saluran peluncur, saluran peredam energi yang dibuat sesuai dengan skala undistorted 1:40.

5. Dimensi dan besar bangunan sesuai dengan hasil akhir (final design) Uji Model Fisik Side Channel Spillway Bendungan Polamaa dengan skala undistorted 1:40.

\subsection{Skala Model}

Pada pengujian ini skala model yang digunakan berdasarkan pertimbangan beberapa hal antara lain : fasilitas yang tersedia di dalam laboratorium; tujuan dari pengujian; ketelitian yang diharapkan; serta waktu dan biaya yang tersedia. Dari hasil analisa ketelitian penetapan skala model, disimpulkan bahwa model fisik pelimpah dengan skala model 1 : 40 sudah sangat memadai, karena untuk debit percobaan yaitu untuk outflow debit banjir rancangan dengan kala ulang 100 tahun $\left(\mathrm{Q}_{100 \mathrm{th}}\right)$ melalui pelimpah diperoleh tingkat kesalahan kedalaman aliran di atas pelimpah 1,82\% atau dengan tingkat ketelitian 98,18 $\%$, sedangkan tingkat kesalahan yang dapat ditoleransi dalam penelitian model tes pada umumnya maksimal adalah $10 \%$.

\subsection{Konstruksi Model}

Uji Model Fisik Side Channel Spillway Bendungan Pomala dibangun semirip mungkin dengan prototipe berdasarkan jenis dan skala tersebut yaitu:

1. Bendungan utama dibuat dengan menggunakan pasangan batu bata dan semen.

2. Pada dasar saluran transisi, ambang pelimpah, peredam energi dan saluran peluncur terbuat dari bahan kayu yang kemudian diperhalus dan dicat agar dapat disesuaikan kesamaan serta kekasaran dengan kondisi prototipe.

3. Untuk dinding pada saluran transisi, peluncur dan peredam energi dibuat menggunakan bahan fiber glass dengan ketebalan $5 \mathrm{~mm}$ supaya dapat diamati kondisi aliran yang sedang terjadi.

\subsection{Persiapan}

Beberapa persiapan dalam melakukan uji model fisik haruslah dilakukan dengan baik, hal ini menyangkut dengan kesiapan dalam melakukan pengambilan data, sehingga hasil yang didapatkan sesuai harapan. Persiapan tersebut antara lain: 


\subsubsection{Alat Ukur Rechbox}

Debit aliran yang masuk ke model diukur dengan ambang tajam tipe Rechbox dengan dimensi yang ditunjukkan Gambar 1 [1].

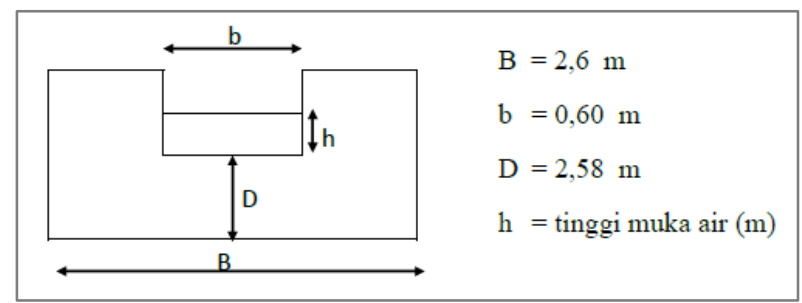

Gambar 1: Alat ukur debit rechbox

Debit aliran teoritik melalui Rechbox dihitung dengan rumus Vennard \& Street [2]:

$$
\begin{array}{lll}
Q & =K . b . h^{3 / 2} & \text { Pers. } 1 \\
K & =107.1+\frac{0.177}{h}+14.2 \frac{h}{D}-25.7 \sqrt{\frac{(B-b) h}{D B}}+2.04 \sqrt{\frac{B}{D}} & \text { Pers. 2 }
\end{array}
$$

dengan :

$Q=\operatorname{debit}\left(\mathrm{m}^{3} / \mathrm{menit}\right)$

$K=$ koefisien debit $\left(\mathrm{m}^{1 / 2} /\right.$ menit $)$

$b \quad=$ lebar mercu $(\mathrm{m})$

$h=$ kedalaman air di atas mercu $(\mathrm{m})$

$B=$ lebar saluran (m)

$D=$ tinggi dari dasar saluran ke dasar mercu (m)

\subsubsection{Pengambilan Data}

Data yang diambil dilakukan pada tiap section yang telah ditentukan berupa [3]:

1. Data tinggi muka air yang diukur dengan menggunakan waterpass.

2. Data tekanan yang diukur dengan menggunakan piezometer.

3. Data kecepatan aliran yang diukur dengan menggunakan tabung pitot (pitot tube)

Sedangkan perhitungan tinggi muka air dengan menggunakan alat ukur point gauge pada ketelitian $0,1 \mathrm{~mm}$ yang dipasang pada titik-titik pengukuran yang ditinjau dan alat ukur debit. Elevasi muka air dapat dihitung menggunakan persamaan berikut [4]:

$$
E=E P G+\left[(I P G-b) x\left(\frac{\text { skala }}{100}\right)\right] \quad \text { Pers. } 3
$$

dengan skala model 1:40, maka:

dengan:

$$
E=E P G+\left[(I P G-b) x\left(\frac{40}{100}\right)\right] \quad \text { Pers. } 4
$$

$\mathrm{E} \quad=$ elevasi muka air prototipe

EPG = elevasi yang digunakan sebagai indeks alat ukur (m)

IPG = bacaan point gauge pada elevasi indeks

$\mathrm{b} \quad=$ bacaan point gauge pada titik yang ditinjau

Pengukuran kecepatan menggunakan alat ukur tabung pitot. Untuk menghitung distribusi kecepatan di prototipe menggunakan persamaan sebagai berikut [5]: 


$$
\begin{aligned}
& V_{m}=C_{d} \sqrt{2 g H} \\
& V_{p}=V_{m} \cdot n_{h}^{1 / 2}
\end{aligned}
$$$$
\text { Pers.5 }
$$

dengan:

$\mathrm{V}_{\mathrm{m}} \quad=$ kecepatan di model $(\mathrm{m} / \mathrm{dt})$

$\mathrm{C}_{\mathrm{p}} \quad=$ koefisien pitot tube $=0,98$

$\mathrm{h} \quad=$ beda tinggi air pada pitot tube $(\mathrm{m})$

$\mathrm{V}_{\mathrm{p}} \quad=$ kecepatan di prototipe

$\mathrm{n}_{\mathrm{h}} \quad=$ skala model

Pengukuran tinggi tekan dengan menggunakan piezometer, untuk menghitung tinggi tekan di prototipe menggunakan persamaan sebagai berikut:

$$
H_{p}=H_{m} \times n_{h}
$$

Pers. 7

dengan:

$\mathrm{H}_{\mathrm{p}} \quad$ = tinggi tekan di prototipe $(\mathrm{m})$

$\mathrm{H}_{\mathrm{m}} \quad$ = tinggi tekan di model $(\mathrm{m})$

$\mathrm{n}_{\mathrm{h}} \quad=$ skala model

Selama berlangsungnya pengujian terhadap berbagai variasi debit, pengamatan dan pengukuran yang dilakukan meliputi:

1. Pola aliran yang terjadi di bangunan pelimpah, saluran samping, saluran transisi, saluran peluncur, peredam energi dan alur sungai bagian hilir.

2. Bahaya kavitasi di pelimpah dan saluran peluncur

3. Efektifitas peredam energi

Pengukuran guna memperoleh data selanjutnya sebagai bahan analisa meliputi:

1. Efektifitas pelimpah dalam pengaliran banjir rancangan

2. Stabilitas dan keamanan hidrolik konstruksi utilitas pelimpah dan peredam energi

3. Alternatif perubahan dimensi bangunan

\subsection{Rancangan Pengujian}

Berdasarkan desain konstruksi \& investigasi lapangan maka pengujian perilaku hidrolika aliran pada pelimpah diuji melalui tahapan dan kondisi model sebagai berikut:

\section{Kalibrasi}

Tahapan kalibrasi merupakan tahapan mencocokkan parameter dari suatu model dan prototipe sehingga akan diperoleh suatu fenomena yang menyerupai. Dalam pengujian model Bendungan Pomalaa, hal yang perlu diperhatikan adalah:

a. Tinggi air di atas pelimpah sesuai dengan debit rencana.

b. Kapasitas saluran harus mampu menjaga kondisi aliran yang tidak menyebabkan aliran balik di atas pelimpah.

c. Kondisi aliran di bagian saluran pengarah dalam kondisi subkritis.

d. Pada akhir transisi sebelum masuk peluncur, kedalaman aliran harus kondisi kritis [6].

2. Verifikasi

Tahapan verifikasi merupakan tahapan pembuktian kebenaraan dari parameter model dan prototype sehingga akan diperoleh validasi yang sesuai ketelitian yang diharapkan [7].

3. Model Original Design

Model Seri 0 merupakan model yang dibuat berdasarkan original design konsultan. 

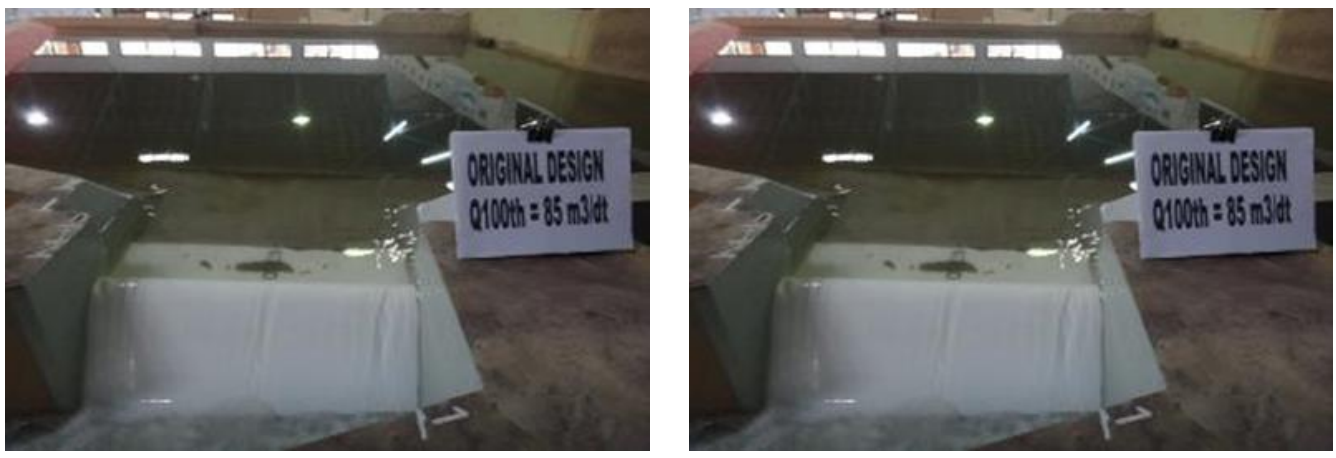

Gambar 2: Kondisi hidrolika di Approach Channel (kiri) dan di pelimpah (kanan)
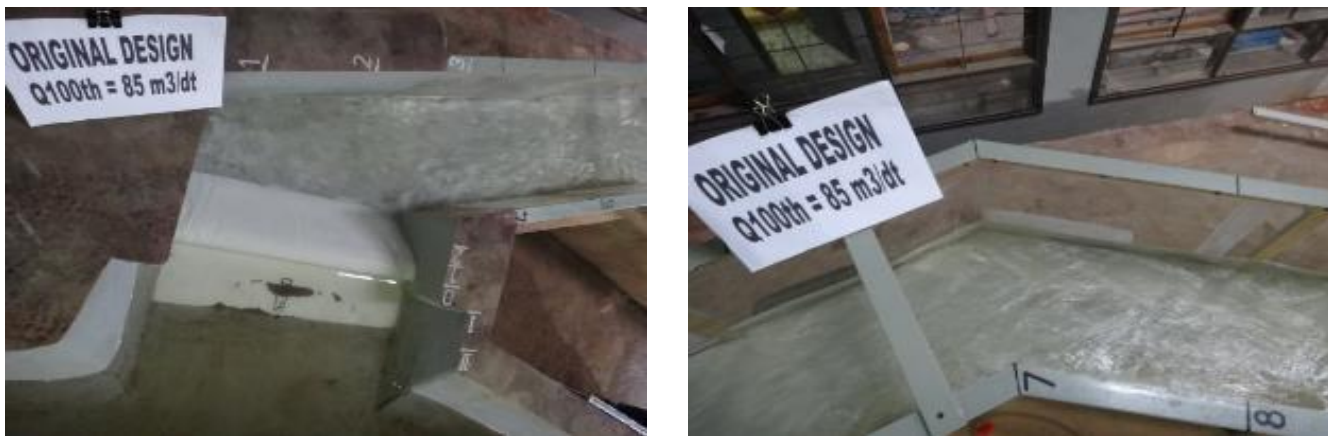

Gambar 3: Kondisi hidrolika di saluran samping (kiri) dan di saluran transisi (kanan)
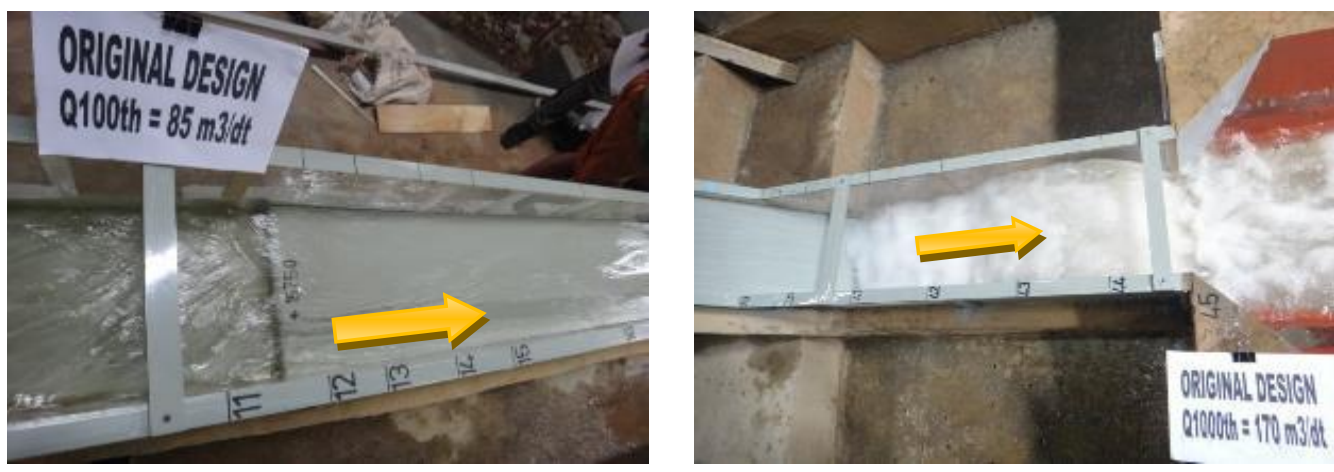

Gambar 4: Kondisi hidrolika di saluran transisi (kiri) dan di saluran peluncur 2 (kanan)
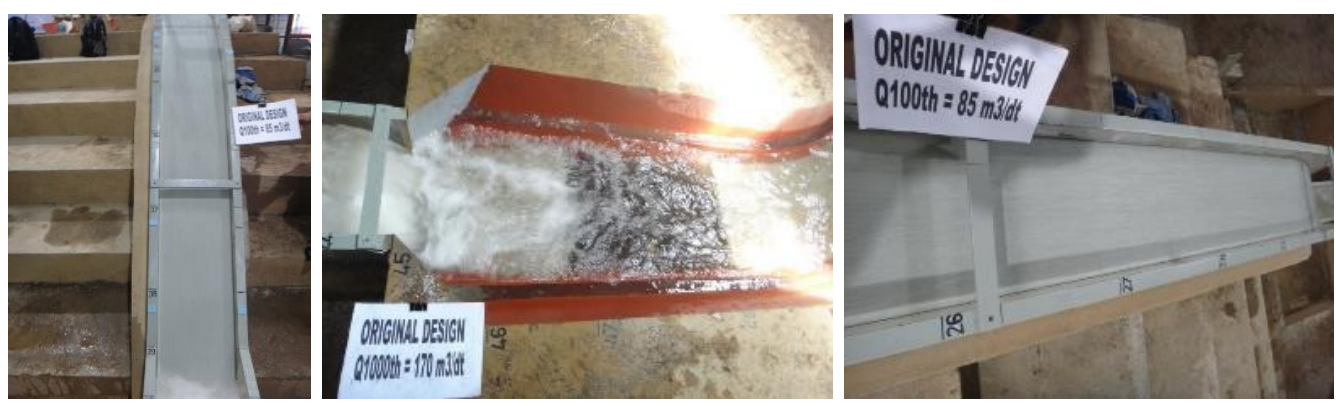

Gambar 5: Kondisi hidrolik di saluran peluncur 3 (kiri), peredam energi (tengah), dan saluran pengarah akhir (kiri) 


\subsection{Rancangan Hasil Pengujian}

Berdasarkan parameter dan rancangan penelitian yang telah disebutkan sebelumnya, maka diharapkan dapat memberikan alternatif hasil yang efektif dan tentu saja aman terhadap keamanan hidrolik konstruksi bangunan itu sendiri.

\section{Hasil Dan Pembahasan}

\subsection{Model Fisik Pelimpah}

Kajian Hidrolika Aliran Bangunan Pelimpah Samping (Side Channel Spillway) Bendungan Pomalaa Kabupaten Kolaka Provinsi Sulawesi Tenggara dengan Uji Model Fisik $1: 40$ ". Tahap ini merupakan peniruan gambar desain dan data teknis bendungan yang telah dirancang untuk kemudian diuji kelayakannya. Kegiatan awal pelaksanaan model test yaitu mempelajari laporan dan gambar desain. Setelah itu, menentukan skala model, membuat mal, pembongkaran model lama, menentukan as model dan mulai pembangunan.

Setelah pembangunan model bendungan selesai, dilakukanlah running test untuk original design. Maksud dari running original design adalah model pelimpah dialiri air dengan debit dan pola operasi yang telah ditentukan dengan desain asli. Original design dari hasil uji model fisik hidrolik pelimpah akan memberikan gambaran profil dan kondisi hidrolik pelimpah Bendungan Pomalaa, dan kemudian akan dilanjutkan pada pemodelan series menggunakan aplikasi.

Dalam rencana skripsi ini, akan dilakukan perhitungan secara teoritis aliran melalui sistem. Kemudian pembandingan antara pengukuran di model fisik dengan perhitungan teoritis, untuk mengetahui tingkat kesalahan yang dimiliki perhitungan. Termasuk untuk mengetahui kajian kapasitas pelimpah dalam mengalirkan desain debit outflow pada 3 kondisi ekstrem yaitu terutama probable maximum flood (PMF).

\subsection{Perhitungan Tinggi Muka Air}

Tinggi muka air diukur dengan alat ukur meteran taraf yang dipasang pada crest alat ukur debit. Elevasi muka air dapat dihitung dengan persamaan berikut [6]:

$$
\text { Elevasi muka air prototipe di titik } \mathrm{A}=E l . P G+\left[\left(I P G-P_{A}\right) \times\left(\frac{L r}{100}\right)\right] \quad \text { Pers. } 8
$$

mengingat skala model adalah 1:40, maka:

Elevasi muka air prototipe di titik A $=E l . P G+\left[\left(I P G-P_{A}\right) \times\left(\frac{40}{100}\right)\right]$ Pers. 9 dengan:

$\mathrm{Y}_{\mathrm{A}} \quad$ : Elevasi muka air prototipe $(\mathrm{m})$

El. PG : Elevasi yang dipakai sebagai indeks ukur (m)

IPG : Pembacaan meteran taraf atau point gauge pada elevasi indeks $(\mathrm{cm})$

$\mathrm{P}_{\mathrm{A}} \quad$ : Pembacaan pada bak ukur di titik tinjau $\mathrm{A}(\mathrm{cm})$

Lr : Skala model 


\subsection{Perhitungan Kecepatan}

Distribusi kecepatan kali ini diukur dengan menggunakan tabung pitot (pitot tube). Adapun persamaan utuk menghitung kecepatan di prototype adalah [8]:

$$
\begin{array}{ll}
V_{m}=C p \times \sqrt{2 g h} & \text { Pers. } 10 \\
V_{p}=V_{m} \times n_{h}{ }^{1 / 2} & \text { Pers. } 11
\end{array}
$$

dengan:

$\mathrm{V}_{\mathrm{m}} \quad$ : Kecepatan di model $(\mathrm{cm} / \mathrm{dt})$

$\mathrm{C}_{\mathrm{p}} \quad$ : Koefisien di tabung pitot 0,98

$\mathrm{h} \quad$ : Beda tinggi air pada tabung pitot $(\mathrm{m})$

$\mathrm{V}_{\mathrm{p}} \quad$ : Kecepatan di prototipe $(\mathrm{m} / \mathrm{dt})$

$\mathrm{n}_{\mathrm{h}} \quad$ : Skala model

\subsection{Perhitungan Tinggi Tekan}

Tinggi tekan kali ini dihitung dengan alat pengukur tekanan berupa piezometer. Adapun persamaan untuk menghitung tinggi tekan adalah [9]:

$$
H_{P}=\left|Y_{A}-Y_{0}\right|
$$

Pers. 12

dengan:

$\mathrm{H}_{\mathrm{p}} \quad$ : Tinggi tekan di prototipe (m)

$\mathrm{Y}_{\mathrm{A}} \quad$ : Elevasi muka air di titik $\mathrm{A}(\mathrm{m})$

$\mathrm{Y}_{0} \quad$ : Elevasi dasar saluran (m)

\subsection{Penentuan Jenis Aliran Bilangan Froude}

Jenis aliran berdasarkan bilangan Froude dihitung menggunakan data kecepatan prototipe dan kedalaman aliran. Dalam menghitung bilangan Froude pada aliran dapat menggunakan rumus sebagai berikut [10]:

$$
F=\frac{V_{P}}{\sqrt{g . H}}
$$

Pers. 13

dengan:

$\mathrm{V}_{\mathrm{p}} \quad$ : Kecepatan di prototipe $(\mathrm{m} / \mathrm{dt})$

g : Percepatan gravitasi $\left(\mathrm{m} / \mathrm{dt}^{2}\right)$

$\mathrm{H} \quad$ : Tinggi air $(\mathrm{m})$

\subsection{Original Design Pelimpah dengan Uji Model Fisik Hidrolik}

Tahap awal dari pengujian model fisik hidrolik kondisi original design Bangunan Pelimpah Samping Pomalaa Kabupaten Kolaka Provinsi Sulawesi Tenggara adalah tahap kalibrasi. Penetapan skala sangat mempengaruhi akurasi kalibrasi, dengan skala yang digunakan pada model fisik ini adalah 1:40 sudah sangat memadai, karena untuk debit percobaan yaitu untuk outflow debit banjir rancangan dengan kata ulang 100 tahun $\left(\mathrm{Q}_{100 \mathrm{th}}\right)$ melalui pelimpah diperoleh tingkat kesalahan kedalaman air di atas pelimpah 1,82\% atau tingkat ketelitian 98,18 \%. Dengan Mengacu pada penetapan skala dengan tingkat 
kesalahan pada umumnya adalah maksimal 10\%, dapat dilihat bahwa secara keseluruhan hasil model telah memenuhi persyaratan. Sehingga hasil model tidak menimbulkan efek skala pada skala 1 : 40, dengan pengertian fenomena hidraulik hasil model akan menyerupai prototipe. Parameter yang digunakan adalah tinggi muka air di atas pelimpah (Hd), dengan kesalahan relatif terbesar diperoleh 3,48 \%.

\subsubsection{Kondisi Original Design pada Waduk dan Saluran Pengarah}

Pengujian dilakukan dengan debit pengaliran kala ulang yaitu $\mathrm{Q}_{100 t h} \mathrm{Q}_{1000 t h}$ dan $\mathrm{Q}_{\text {PMF. }}$ Ditinjau dari elevasi muka air, model pada pelimpah samping Bendungan Pomalaa mampu mengalirkan air pada semua debit rancangan yang diujikan tanpa menimbulkan overtopping.

Untuk perilaku alirannya, terlihat pada dinding saluran hantar hulu (approach channel) yang cukup panjang membuat aliran yang menuju pelimpah menjadi tenang pada setiap debit yang diujikan sehingga tidak diperlukan adanya perubahan. Pada semua debit terindikasi adanya sedikit gangguan aliran di tebing kanan dan kiri arah masuk saluran pengarah. Namun secara keseluruhan tidak terlalu berpengaruh pada kondisi aliran di saluran pengarah.

\subsubsection{Kondisi Original Design pada Pelimpah}

Elevasi muka air pada model pelimpah dari $\mathrm{Q}_{100 \text { th }}$ hingga $\mathrm{Q}_{\mathrm{PMF}}$ tidak terjadi aliran balik (backwater) sehingga mampu melewatkan semua debit rancangan. Jika melihat pembacaan yang terpasang pada piezometer dipelimpah, menunjukkan pada debit banjir rancangan $\mathrm{Q}_{1000 t h}$ dan $\mathrm{Q}_{\mathrm{PMF}}$ terdapat nilai negatif, akan tetapi tidak melebihi -4 m. Dengan perhitungan menggunakan data kecepatan (V) dan tinggi muka air (h) menunjukkan adanya gejala kavitasi di pelimpah pada kondisi $\mathrm{Q}_{1000 t h}$ dan QPMF pada section 2.

\subsubsection{Kondisi Oiginal Design pada Saluran Samping}

Ditinjau dari pemodelan dan pengukuran kapasitas saluran samping dan elevasi muka air, yang memiliki panjang 21,920 m mampu mengalirkan dengan aman pada semua debit rancangan $\left(\mathrm{Q}_{100 t h} \mathrm{~S} / \mathrm{d} \mathrm{Q}_{\mathrm{PMF}}\right)$ yang dioperasikan di model.

Sedangkan pada perilaku aliran, section 1 dan 2 pada debit $\mathrm{Q}_{1000 \text { th }}$ mengalami aliran superkritis (Froude diatas 1) sedangkan pada section 1, 2 dan $3\left(\mathrm{Q}_{100 t h}\right.$ dan $\left.\mathrm{QPMF}_{\mathrm{PM}}\right)$ mengalami aliran subkritis (Froude dibawah 1).

\subsubsection{Kondisi Oiginal Design pada Saluran Transisi}

Ditinjau dari pemodelan dan pengukuran kapasitas saluran transisi yang memiiki panjang 101,08 meter dan elevasi muka air, yang dioperasikan di model dapat mengalirkan air dengan aman pada semua debit rancangan $\left(\mathrm{Q}_{100 \text { th }} \mathrm{s} / \mathrm{d} \mathrm{Q}_{\mathrm{PMF}}\right)$. Sedangkan pada kontrol terhadap bahaya fenomena kavitasi, terlihat pada dasar saluran transisi dari piezometer yang terpasang, pada semua pengaliran debit banjir rancangan $\left(\mathrm{Q}_{100 \text { th }} \mathrm{s} / \mathrm{d} \mathrm{Q}_{\mathrm{PMF}}\right)$ tidak menunjukkan adanya nilai negatif. Pada ujung hilir saluran transisi terdapat ambang setinggi 1,5 m yang efektif untuk penciptaan aliran tenang di saluran transisi dan mampu menjadi bagian kontrol aliran dengan baik. Sehingga secara garis besar, perilaku hidrolik pada saluran transisi ini aliran yang yang terjadi masih belum seragam. 


\subsubsection{Kondisi Oiginal Design pada Saluran Peluncur 1}

Ditinjau dari pemodelan dan pengukuran elevasi muka air, kapasitas saluran peluncur 1 dengan panjang 170 meter dan lebar 14 meter pada semua debit rancangan $\left(\mathrm{Q}_{100 t h} \mathrm{~s} / \mathrm{d}\right.$ QPMF) yang dioperasikan di model dapat mengalirkan dengan aman.

Sedangkan pada kontrol terhadap bahaya fenomena kavitasi menunjukkan adanya nilai negatif pada semua pengaliran debit banjir rancangan $\left(\mathrm{Q}_{100 \text { th }} \mathrm{S} / \mathrm{d} \mathrm{Q}_{\mathrm{PMF}}\right)$ yang terlihat pada piezometer yang terpasang pada dasar saluran peluncur 1. Sehingga secara garis besar, perilaku hidrolik pada debit $\mathrm{Q}_{100 t h}$ saluran peluncur 1 terdapat aliran silang (cross flow) pada bagian hilir.

\subsubsection{Kondisi Oiginal Design pada Saluran Peluncur 2}

Ditinjau dari pemodelan dan pengukuran elevasi muka air, Kapasitas saluran peluncur 2 dengan panjang 110 meter dan lebar 14 meter untuk semua debit rancangan $\left(Q_{100 t h} \mathrm{~s} / \mathrm{d}\right.$ QPMF) yang dioperasikan di model dapat mengalirkan dengan aman.

Sedangkan pada kontrol menunjukkan pada piezometer yang terpasang di dasar saluran peluncur 2 adanya nilai negatif pada semua pengaliran debit banjir rancangan $\left(\mathrm{Q}_{100 \text { th }} \mathrm{s} / \mathrm{d}\right.$

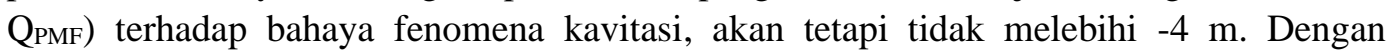
perhitungan menggunakan data kecepatan (V) dan tinggi muka air (h) menunjukkan adanya kavitasi di peluncur 2 pada kondisi $\mathrm{Q}_{100 t h}$ dan $\mathrm{Q}_{1000 t \text { th. }}$ Sehingga secara garis besar, perilaku hidrolik pada saluran peluncur 2 kondisi aliran masih terjadi aliran silang.

\subsubsection{Kondisi Oiginal Design pada Saluran Peluncur 3}

Ditinjau dari pemodelan dan pengukuran elevasi muka air, Kapasitas saluran peluncur 3 dengan panjang 50 meter dan lebar 14 meter pada semua debit rancangan $\left(\mathrm{Q}_{100 \mathrm{th}} \mathrm{S} / \mathrm{d} \mathrm{Q}_{\mathrm{PMF}}\right)$ yang dioperasikan di model dapat mengalirkan dengan aman.

Sedangkan pada kontrol terhadap bahaya fenomena kavitasi pada dasar saluran peluncur 3, pada piezometer yang terpasang menunjukkan pada semua pengaliran debit banjir rancangan $\left(\mathrm{Q}_{100 \text { th }} \mathrm{s} / \mathrm{d} \mathrm{Q}_{\mathrm{PMF}}\right)$, terdapat nilai negatif akan tetapi tidak melebihi $-4 \mathrm{~m}$. Dengan perhitungan menggunakan data kecepatan (V) dan tinggi muka air (h) menunjukkan adanya kavitasi di peluncur 3 pada kondisi $\mathrm{Q}_{100 t h}$ dan $\mathrm{Q}_{1000 \text { th. }}$ Sehingga secara garis besar, perilaku hidrolik pada saluran peluncur 3 kondisi aliran masih belum seragam, tinggi muka air tidak merata.

\subsubsection{Kondisi Oiginal Design pada Saluran Peredam Energi}

Ditinjau dari pemodelan dan pengukuran elevasi muka air, Secara keseluruhan setiap debit rancangan yang lewat pada $\mathrm{Q}_{100 t \mathrm{th}}$ dan $\mathrm{Q}_{1000 \mathrm{th}}$ dan tinggi dinding peredam energi masih mampu menampung Namun saat $Q_{P M F}$, terjadi loncatan yang relatif tinggi, sehingga perlu penambahan tinggi dinding. Sedangkan pada kontrol menunjukkan adanya nilai negatif di semua pengaliran debit banjir rancangan terhadap bahaya fenomena kavitasi dari piezometer yang terpasang di dasar saluran peredam energi. Sehingga kesimpulan yang diperoleh bahwa peredam energi aman terhadap bahaya kavitasi. Dengan menggunakan perhitungan juga tidak ditemukan adanya kavitasi pada semua debit pengaliran. 
Sehingga secara garis besar, perilaku hidrolik pada peredam energi di debit pengujian $\mathrm{Q}_{100 \mathrm{th}}$ dan $\mathrm{Q}_{1000 \mathrm{th}}$, loncatan hidrolik terjadi di bagian dalam ruang olak, sehingga kondisi hidrolik alirannya masih dapat dikatakan baik. Namun pada debit QPMF loncatan hidrolik yang terjadi cukup tinggi yang dapat membahayakan kondisi dasar sungai di hilinna. Sehingga perlu dilakukan perlakuan atau bagian perubahan pada peredam energi. Salah satunya adalah dengan meninggikan dinding peredam energi kurang lebih 4 meter.

\subsubsection{Kondisi Oiginal Design pada Saluran Pengarah Akhir}

Perilaku hidrolik pada pengarah akhir, kondisi aliran pada saluran pengarah hilir pada $\left(\mathrm{Q}_{100 t \mathrm{th}}\right.$ dan $\left.\mathrm{Q}_{1000 \mathrm{th}}\right)$ terjadi aliran yang merata. Pada saat $\mathrm{QPMF}_{\mathrm{PM}}$ aliran tidak merata, namun aliran belum relatif tenang dengan jenis aliran bervariasi subkritis dan superkritis.

\subsubsection{Pembahasan Hidrolika Kondisi Original Design}

Setelah dilakukan pengujian debit banjir dengan kondisi original design, didapatkan data sebagai berikut.

Tabel 1: Rekapitulasi nilai kecepatan saluran pengarah (approach channel) original design

\begin{tabular}{cccccc}
\hline No. & $\begin{array}{c}\text { Debit } \\
\text { Banjir }\end{array}$ & $\begin{array}{c}\mathrm{V} \\
(\mathrm{m} / \mathrm{dt})\end{array}$ & $\begin{array}{c}\text { Syarat } \\
\mathrm{V}<4 \mathrm{~m} / \mathrm{dt}\end{array}$ & $\begin{array}{c}\text { Elevasi } \\
\text { Muka Air }(\mathrm{m})\end{array}$ & $\begin{array}{c}\text { Tinggi Jagaan } \\
\text { terhadap Puncak } \\
\text { Bendungan }(\mathrm{m})\end{array}$ \\
\hline 1 & $\mathrm{Q}_{100}$ & 1,32 & Memenuhi & 166,490 & 3,51 \\
2 & $\mathrm{Q}_{1000}$ & 2,31 & Memenuhi & 167,160 & 2,84 \\
3 & $\mathrm{Q}_{\text {PMF }}$ & 3,50 & Memenuhi & 168,270 & 1,73 \\
\hline
\end{tabular}

Berdasarkan data dari tabel 1 dapat disimpulkan bahwa seluruh debit banjir $\mathrm{Q}_{100 t h}$ sampai QPMF yang diujikan telah memenuhi syarat terhadap batas kecepatan yang diperbolehkan dan tinggi jagaan juga aman terhadap semua debit.

Pengukuran hidrolika aliran pada peredam energi dilakukan di tengah 6 titik pengukuran. Pada tabel 2. dapat dilihat hasil pengukuran kondisi hidrolika aliran ditengah kolam olak (section 39).

Tabel 2: Rekapitulasi Kondisi Aliran di Peredam

\begin{tabular}{cccccc}
\hline No. & $\begin{array}{c}\text { Debit } \\
\text { Banjir }\end{array}$ & $\begin{array}{c}\text { Kecepatan } \\
(\mathrm{m} / \mathrm{dt})\end{array}$ & $\begin{array}{c}\mathrm{H} \text { air } \\
(\mathrm{m})\end{array}$ & $\begin{array}{c}\text { Bilangan } \\
\text { Froude }\end{array}$ & Jenis Aliran \\
\hline 1 & $\mathrm{Q}_{100}$ & 2.38 & 7.53 & 0.28 & Subkritis \\
2 & $\mathrm{Q}_{1000}$ & 8.33 & 7.79 & 0.95 & Subkritis \\
3 & $\mathrm{Q}_{\mathrm{PMF}}$ & 0.00 & 14.11 & 0.00 & - \\
\hline
\end{tabular}

Pada debit $\mathrm{Q}_{100 \text { th }}$ dan $\mathrm{Q}_{1000 \text { th }}$ kecepatan air dapat diamati menggunakan alat ukur kecepatan, akan tetapi untuk debit QPMF kecepatan tidak bisa diamati dikarenakan air mengandung banyak udara. Pada QPMF loncatan terjadi setelah kolam olak sehingga membahayakan kondisi hilirnya. Pada kondisi aliran tersebut terjadi pengolakan pada peredam energi sehingga terjadi aliran superkritis sehingga akan membahayakan bangunan 
hilirnya. Sehingga perlu dilakukan perlakuan atau bagian perubahan pada peredam energi. Salah satunya adalah dengan meninggikan dinding peredam energi kurang lebih 4 meter.

Pengamatan kondisi hidrolika aliran disaluran pengarah hilir dilakukan pada 10 section, dimulai dari hilir kolam olak (section 43 sampai 52). Berikut adalah pengamatan pada section 48.

Tabel 3: Rekapitulasi Kondisi Aliran di Saluran Pengarah Hilir Original Design

\begin{tabular}{cccccc}
\hline No. & $\begin{array}{c}\text { Debit } \\
\text { Banjir }\end{array}$ & $\begin{array}{c}\text { Kecepatan } \\
(\mathrm{m} / \mathrm{dt})\end{array}$ & $\begin{array}{c}\text { H air } \\
(\mathrm{m})\end{array}$ & $\begin{array}{c}\text { Bilangan } \\
\text { Froude }\end{array}$ & Jenis Aliran \\
\hline 1 & $\mathrm{Q}_{100}$ & 2.38 & 7.53 & 0.28 & Subkritis \\
2 & $\mathrm{Q}_{1000}$ & 8.33 & 7.79 & 0.95 & Subkritis \\
3 & Q & 0.00 & 14.11 & 0.00 & - \\
\hline
\end{tabular}

Pada tabel 3 dapat diketahui bahwa jenis aliran pada debit pengujian $\mathrm{Q}_{100 t h,} \mathrm{Q}_{1000 t \text { th, }}$ dan $\mathrm{Q}_{\mathrm{PMF}}$ adalah superkritis dengan bilangan Froude $>1$.

\subsection{Analisa Hidrolik Pelimpah Kondisi Original Design dengan Pendekatan Teoritis}

Debit aliran melalui pelimpah dapat dihitung dengan menggunakan pendekatan persamaan koefisien debit.

Pada Bendungan Pomalaa perencanaan pelimpah dengan menggunakan debit rencana $\mathrm{Q}_{1000 t h}$. Data hasil perhitungan penelusuran debit banjir yang berupa debit outflow digunakan untuk keperluan pengujian model fisik hidrolika tentang waduk.
a. $\mathrm{Q}_{100 \mathrm{th}} \quad: 85,00 \mathrm{~m}^{3} / \mathrm{dt}$
b. Q 1000 th $: 170,00 \mathrm{~m}^{3} / \mathrm{dt}$
c. QPMF : $385,00 \mathrm{~m}^{3} / \mathrm{dt}$

\subsubsection{Perhitungan Koefisien Debit melalui Ambang Pelimpah}

Koefisien debit $(\mathrm{C})$ dari ambang pelimpah diperoleh dengan pendekatan perhitungan metode Iwasaki. Dengan menggunakan persamaan B' $=$ B-2(n.Kp $+\mathrm{Ka}) \mathrm{He}$ makan didapatkan nilai B' sebesar 22,480 $\mathrm{m}$ dan $\mathrm{Cd} 2,17$ sehinggan diperoleh $\mathrm{Q}=173,45 \mathrm{~m}^{3} / \mathrm{ft}$

\subsubsection{Perhitungan Profil Muka Air Pada Pelimpah}

Pelimpah samping (side channel spillway) digunakan pada Bendungan Pomalaa dengan Mercu pelimpah memiliki lebar $23 \mathrm{~m}$ dan tinggi 2 meter. Persamaan standar digunakan dalam perhitungan profil muka air di atas ambang pelimpah, maka dapat diketahui profil muka air diatas pelimpah.

3.8. Perbandingan Uji Model Fisik Hidrolik dengan Analisa Hidrolika secara Teoritis pada Ambang Pelimpah

Setiap pemodelan hidrolik ataupun analisa perhitungan secara eksak akan memiliki tingkat kesalahan tersendiri. Bahkan banyak hal dan fenomena yang secara analitis hidrolik tidak dapat menjelaskan secara nyata kejadian yang nyata terjadi di kondisi eksisting. 
Tabel 4: Perbedaan Hasil Model Fisik dengan Analisa Teoritis pada Ambang Pelimpah

\begin{tabular}{|c|c|c|c|c|c|c|c|c|}
\hline \multirow{2}{*}{ No } & \multirow{2}{*}{$\begin{array}{c}\text { Kala } \\
\text { Ulang } \\
\text { (tahun) }\end{array}$} & \multirow{2}{*}{$\begin{array}{c}\mathrm{Q} \\
\text { outflow } \\
\left(\mathrm{m}^{3} / \mathrm{dt}\right)\end{array}$} & \multicolumn{2}{|c|}{$\begin{array}{c}\text { Tinggi Muka Air } \\
\text { diatas Pelimpah }(\mathrm{Hd})\end{array}$} & \multicolumn{2}{|c|}{$\begin{array}{c}\text { Koefisien } \\
\text { Limpahan }(\mathrm{Cd})\end{array}$} & \multicolumn{2}{|c|}{$\begin{array}{l}\text { Presentase } \\
\text { Perbedaan }\end{array}$} \\
\hline & & & $\begin{array}{c}\text { Model } \\
\text { (m) }\end{array}$ & $\begin{array}{c}\text { Iwasaki } \\
\text { (m) }\end{array}$ & $\begin{array}{l}\text { Model } \\
\left(\mathrm{m}^{1 / 2} / \mathrm{dt}\right)\end{array}$ & $\begin{array}{l}\text { Iwasaki } \\
\left(\mathrm{m}^{1 / 2} / \mathrm{dt}\right)\end{array}$ & $\begin{array}{c}\text { Tinggi } \\
\text { Muka Air } \\
(\%)\end{array}$ & $\begin{array}{c}\text { Koefisien } \\
\text { Limpasan } \\
(\%)\end{array}$ \\
\hline 1 & 100 & 85,09 & 1,71 & 1,44 & 5,44 & 2,18 & $19,0 \%$ & $51,7 \%$ \\
\hline 2 & 1000 & 173,45 & 2,21 & 2,33 & 5,72 & 2,17 & $5,3 \%$ & $48,1 \%$ \\
\hline 3 & $\mathrm{PMF}$ & 385,85 & 4,08 & 4,05 & 6,46 & 2,14 & $0,6 \%$ & $47,1 \%$ \\
\hline
\end{tabular}

Secara teoritis dimensi ambang pelimpah sangat mempengaruhi tinggi muka air di atas ambang tersebut. Dimensi lebar, bentuk atau tipe ambang dan tinggi ambang adalah parameter utama untuk mengetahui tinggi air di atas ambang. Tinggi di atas ambang sangat mempengaruhi tipe aliran yang terjadi pada kondisi pengaliran debit banjir rancangan tepatnya debit outflow. Pada tabel 4 diatas dapat ditampilkan perbandingan koefisien dan tinggi muka air di ambang pelimpah model fisik dengan hasil analisa teoritis.

\subsection{Perhitungan Indeks Kavitasi}

Sebagai contoh perhitungan indeks kavitasi menggunakan debit $\mathrm{Q}_{100 t h}$ pada Model Fisik Original Design bagian section II saluran pengarah dengan tinggi muka air (h) dan kecepatan aliran (v) yang didapat dari hasil perhitungan [8]. Berdasarakan pada perhitungan kavitasi menggunakan kecepatan air (v) dan kedalaman air (h) menunjukkan adanya kavitasi di saluran peluncur 2 dan 3 pada debit $\mathrm{Q}_{100 t h}$ dan $\mathrm{Q}_{1000 t h}$.

\subsection{Rekomendasi Perubahan}

Berdasarkan kondisi pelaksanaan dan pengujian model hidrolik pelimpah Bendungan Pomalaa maka direkomendasikan untuk melakukan perubahan desain sistem pelimpah dari original design menjadi sebagai berikut :

1. Ditambahkan sill pada bagian saluran transisi setinggi 2,3. Diletakkan pada 27,099 m dari awal saluran transisi.

2. Dasar kolam olak diturunkkan $5 \mathrm{~m}$ dari elevasi $+46 \mathrm{~m}$ menjadi $+41 \mathrm{~m}$. Tinggi end sill diturunkan dari 5,3 m menjadi $3 \mathrm{~m}$.

3. Setelah kaki hilir end sill diberikan kemiringan negatif 1:5 ke hilir.

4. Untuk menjaga kestabilan struktur sistem pelimpah, terutama pada bagian saluran peluncur yang terjadi tekanan negatif (walaupun tidak melebihi $-4 \mathrm{~m}$ ), maka direkomendasikan untuk menambahkan aerator sebagai pencegahan terhadap bahaya kavitasi.

\section{Kesimpulan}

4.1. Kesimpulan

Berdasarkan hasil penelitian ini maka diperoleh kesimpulan sebagai berikut:

1. Terjadi aliran yang tidak seragam pada saluran transisi. 
2. Piezometer menunjukkan adanya tekanan negatif pada saluran peluncur 2 dan 3 , akan tetapi masih dibatas aman. Tidak melebihi $-4 \mathrm{~m}$. Akan tetapi pada perhitungan kavitasi menggunakan kecepatan air (v) dan kedalaman air (h) menunjukkan adanya kavitasi di saluran peluncur 2 dan 3 pada debit $\mathrm{Q}_{100 t h}$ dan $\mathrm{Q}_{1000 \text { th. }}$.

3. Terjadi aliran superkritis pada saluran akhir setelah peredam energi.

4. Terjadi kesalahan elevasi dasar pada seri ini, sehingga harus menaikkan bangunan kurang lebih setinggi $40 \mathrm{~cm}$ dari awal ambang pelimpah sampai akhir saluran peluncur 2. Awal saluran peluncur 3 sampai akhir saluran berada pada elevasi tetap.

5. Untuk menjaga kestabilan struktur sistem pelimpah, terutama pada bagian saluran peluncur yang terjadi tekanan negatif (walaupun tidak melebihi - $4 \mathrm{~m}$ ), maka disarankan untuk menambahkan aerator sebagai pencegahan terhadap bahaya kavitasi.

\subsection{Saran}

Berdasarkan perhitungan analitis dan pengujian yang telah dilaksanakan pada penelitian ini maka saran yang diperoleh adalah bahwa didalam pendekatan hidrolika sebaiknya peneliti tetap mengacu pada uji model. Hal ini dikarenakan pada teori yang ada belum tentu bisa memenuhi kondisi yang terjadi di lapangan. Sedangkan saran yang dapat diberikan untuk laboratorium adalah perlunya dilakukan pengukuran ulang pada sectionsection yang terdapat gelembung, karena data yang kosong sangat mempengaruhi proses kelancaran perhitungan.

\section{Daftar Pustaka}

[1] Anonim, Laporan Model Test Pelimpah (Spillway) Pomalaa Tailing Dams Shoutheast Sulawesi. Malang: Jurusan Pengairan FT-UB, 2019.

[2] J.K. Vennard, dan R.L. Street, Elementary Fluid Mechanics, pp.143-145. New York : John Wiley \& Sons, 1982.

[3] Direktorat Jenderal Sumber Daya Air, Standar Perencanaan Irigasi KP-04. Jakarta: Kementerian Pekerjaan Umum, 2013.

[4] S. Sosrodarsono dan K. Tekeda, Bendungan Type Urugan. Jakarta: Erlangga, 1989.

[5] Y. Nur, Perencanaan Model Hidraulik (Hydraulic Modelling). Yogyakarta: Laboratorium Hidraulik dan Hidrologi Universitas Gajah Mada, 1994.

[6] Anonim, Laporan Akhir Model Test Spillway Bendungan Tiu Suntuk Kabupaten Sumbawa Barat. Malang: Jurusan Pengairan FT-UB, 2017.

[7] S. Sosrodarsono dan K. Tekeda, Bendungan Type Urugan. Jakarta: Erlangga, 1977.

[8] V.T. Chow, Open Channel Hydraulic, Terjemahan E. V. Nensi Rosalina. Jakarta: Erlangga, 1992.

[9] Roberson, et.al, Hydraulic Engineering 2nd (second) edition. Wiley, 1998.

[10] B. Triatmojo, Hidrolika II, Yogyakarta: Beta Offset, 1996. 